\title{
THE EFFECT OF LEARNING WITH ABDUCTIVE-DEDUCTIVE STRATEGY ON HIGH SCHOOL STUDENTS' REASONING ABILITY
}

\author{
Ali Shodikin \\ Mathematics Education, Indonesia University of Education \\ aliandr4@gmail.com
}

First draft received: 24 July 2016

Final proof received: 20 August 2017

\begin{tabular}{|c|}
\hline $\begin{array}{l}\text { Abstract } \\
\text { The purpose of this research is to investigate the effect of learning with abductive-deductive strategy on } \\
\text { the achievement of mathematical reasoning abilities of high school students. It employed the } \\
\text { experimental pretest-posttest with non-randomized control group design to the eleventh grade students } \\
\text { of one high school in Pati, Central Java, Indonesia. Data were collected in the form of early } \\
\text { mathematical ability categories (EMA) and overall. The results showed that the achievement of } \\
\text { mathematical reasoning abilities that students acquire through learning with abductive-deductive } \\
\text { strategy was better than that of the students who received were taught with expository learning. In more } \\
\text { detail, only students in the medium category of EMA showed better achievement in mathematical } \\
\text { reasoning abilities. Meanwhile, students of the upper and lower categories had the same achievements } \\
\text { in their reasoning abilities. Based on the findings of the research, it is expected that teachers can } \\
\text { encourage students to apply abduction and deduction strategy in order to achieve in mathematical } \\
\text { reasoning abilities. }\end{array}$ \\
\hline Keywords: abductive-deductive strategy; mathematical reasoning, early mathematical ability. \\
\hline $\begin{array}{l}\text { To cite this paper (in APA style): } \\
\text { Shodikin, A. (2017). The effect of learning with abductive-deductive strategy on high school students' } \\
\text { reasoning ability. International Journal of Education, } 10(1), \quad 67-72 . \quad \text { doi: } \\
\text { http://dx.doi.org/10.17509/ije.v10i1.8080 }\end{array}$ \\
\hline
\end{tabular}

\section{INTRODUCTION}

Mathematical reasoning ability is the main characteristic that cannot be separated from the activities of studying and developing or solving mathematical problems (Ansjar \& Sembiring, 2000). In fact, the implementation of learning that emphasizes the existence of reasoning is very recommended (NCTM, 2000). However, many studies show that the reasoning ability of students in Indonesia is still low (Rahayu, 2013). Although reasoning ability is needed in mastering and solving mathematical problems (Wahyudin, 1999), this ability is often overlooked in learning (Nizar, 2007). Therefore, in learning mathematics, mathematical reasoning ability should be given special attention.

Reports of the results of other studies support the arguments. Reasoning ability is a part of higher order mathematical thinking abilities (Sumarmo, 2013). However, studies conducted by Henningsen \& Stein (1997), Mullis et al. (2000), Suryadi (2005), and Murni (2013) show that learning mathematics is generally not focused on developing higher order mathematical thinking abilities. Students more frequently solve problems from the textbook and get less non-routine problems that can train these higher order mathematical thinking abilities. Thus, efforts to develop mathematics learning oriented to the development of higher order thinking abilities are needed.
Based on a preliminary analysis of reasoning ability, it is necessary to develop a learning that can improve the understanding of essential concepts. The general framework in solving a problem in mathematics is the ability to identify the given facts (data) and formulate what is asked in the problem (final target). Determining the final target is based on data provided, and it is necessary to elaborate the ability to apply the essential concepts that are relevant with the given data to obtain intermediate target before finding the answer to the final target. Not a few problems in mathematics can be more easily solved by adding a condition (intermediate target) that is based on a relevant concept to arrive at the final target in question.

The general framework as described above has been developed in the research of Kusnandi (2008) on learning with abductive-deductive strategy (PSAD). Abductive is a mathematical thinking skill (reasoning) that cannot fully answer a problem, but it is a process of offering a reason as the basis for a specific action (Aliseda, 2007). This general framework was originally developed to develop the proving ability of students who just begin learning about proof. The results showed that students who learn with abductive-deductive strategy have better proving ability than students who learn with conventional learning. Possible application of this strategy has been reviewed as well by Sun et al. 
(2005) for the problem of reasoning and problem solving ability. The possibility of applying this framework to the wide range of problems (mathematical literacy) for students in secondary schools has also been studied theoretically (Shodikin, 2013), but not at the practical level. Herein, the present study attempts to find out whether abductive- deductive strategy has effects on high school students' reasoning ability.

Based on the notion of learning with abductive-deductive strategy, in this study a more operational learning syntax of abductive-deductive strategy is developed as shown in Figure 1.

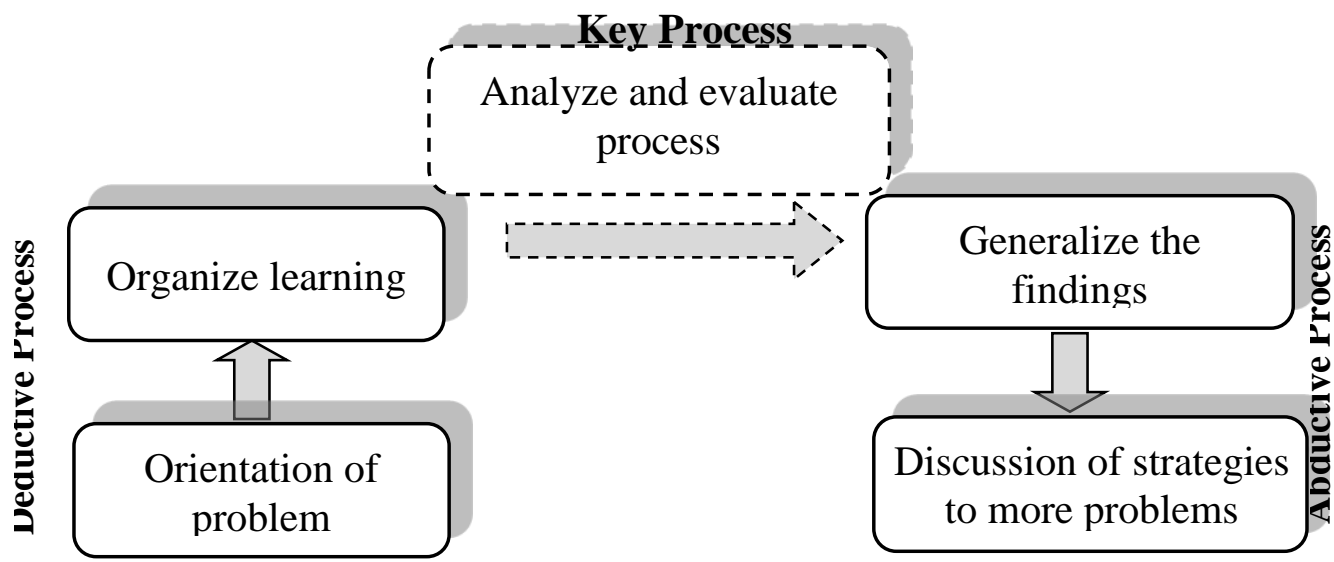

Figure 1. Schematic of Learning with Abductive-Deductive Strategy

The stages of learning with abductive-deductive strategy above are described in more detail in Table 1 .

Table 1. The Syntax of Learning with Abductive-Deductive Strategy

\begin{tabular}{|c|c|c|}
\hline \multicolumn{2}{|r|}{ Phase } & Teacher Behavior \\
\hline Phase 1 & Orientation of problem & $\begin{array}{l}\text { - Teacher discusses the problem of learning objectives } \\
\text { - Teachers describe various important logistics needs } \\
\text { - Teachers motivate students to be directly involved in learning } \\
\text { activities } \\
\text { - Teachers provide apperception }\end{array}$ \\
\hline Phase 2 & $\begin{array}{l}\text { Organization of } \\
\text { learning }\end{array}$ & $\begin{array}{l}\text { - Teachers help students to define and organize the tasks of } \\
\text { learning and information related to the problem }\end{array}$ \\
\hline Phase 3 & $\begin{array}{l}\text { Analysis and process } \\
\text { evaluation }\end{array}$ & $\begin{array}{l}\text { - Analyze and evaluate the teacher directs students to find their } \\
\text { own solutions from information already possessed by students } \\
\text { - Teachers encourage students to do transactive reasoning as to } \\
\text { criticize, explain, clarify, justify and elaborate a proposed idea, } \\
\text { either initiated by students and teachers } \\
\text { - Teachers assist students in planning and preparing materials for } \\
\text { presentations and discussion } \\
\text { - Teachers help students to reflect on the investigation process } \\
\text { and other processes used in solving problems }\end{array}$ \\
\hline Phase 4 & $\begin{array}{l}\text { Generalization of the } \\
\text { findings }\end{array}$ & - Teachers help generalize the findings obtained \\
\hline Phase 5 & $\begin{array}{l}\text { Discussion of } \\
\text { strategies to more } \\
\text { problems }\end{array}$ & $\begin{array}{l}\text { - Teachers assist students in finding more strategies for the } \\
\text { problems } \\
\text { - Teachers provide training and evaluation }\end{array}$ \\
\hline
\end{tabular}

To be involved in transactive discussion, students' early mathematics ability (EMA) plays a very important role, by which the idea that appears to develop gradually so as to build a comprehensive mathematical concept of information is obtained. Students' EMA are divided into three categories: upper, middle, and lower levels. This grouping is used to see if there is mutual effect between the learning done and students' early mathematics ability and reasoning abilities. Besides that, the effects of learning in each category of early mathematical ability can be explained.
Based on the background and formulation of the problem described above, this study aims to investigate the effect of learning with abductivedeductive strategy on the achievement of high school students' mathematical reasoning abilities.

\section{METHODOLOGY}

The method applied in this study was the experimental with pretest-posttest with nonrandomized control group design. With this design, subjects initially performed pretest, and then treated with a form of learning with abductive-deductive strategy and subsequently performed post-test to 
measure their mathematical reasoning abilities in the topic of polynomial. This design was chosen according to the purpose of the research, namely to show the effect of the application of learning with

\begin{tabular}{|l|ccc|}
\hline Experimental Class & $\mathrm{O}$ & $\mathrm{X}_{1}$ & $\mathrm{O}$ \\
\cline { 4 - 5 } & pretest & treatment & posttest \\
\hline Control Class & $\mathrm{O}$ & $\mathrm{X}$ & $\mathrm{O}$ \\
\cline { 3 - 4 } & pretest & expository & posttest \\
\hline
\end{tabular}

Figure 2. Research Design
The study was conducted at one high school in Pati, Central Java, Indonesia, in the academic year of 2013/2014. The samples consisted of two classes that have the same early mathematical abilities out of the eight classes available with purposive sampling, each totaling to 34 students. The grouping of students by the category early mathematical ability was done based on the average scores of two daily tests: mid semester test and end-of-semester test. The weights of these values were $20 \%, 30 \%$, and $50 \%$, respectively. abductive-deductive strategy on the achievement of students' mathematical reasoning ability. The research design is presented in Figure 2.

\section{FINDINGS}

The selection of the class used as the research sample, in addition to being based on early mathematical abilities was also based on the initial reasoning abilities shown by the pretest scores, both overall and by EMA category. The findings revealed that the students who learned with abductive-deductive strategy and those with expository method showed no differences in early mathematical ability and reasoning ability, both as a whole and by category of EMA (upper, middle, lower).

The achievement of mathematical reasoning ability was determined based on the posttest scores. Details of the achievement are provided in Figure 3.

\section{$\square$ upper $\square$ middle $\square$ under $\square$ overall}

30

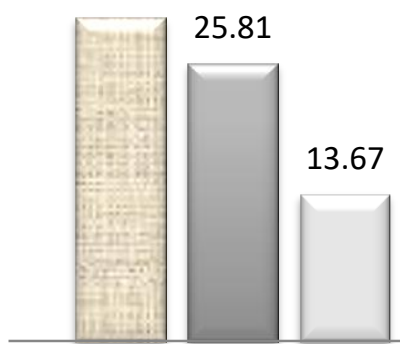

Experimental
30

24.53

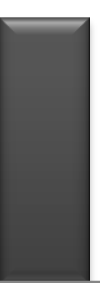

15.88

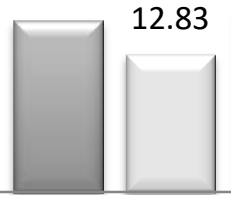

17

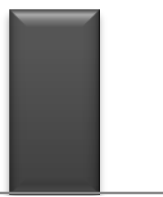

Control

Figure 3. Achievement Score Bar Chart

\section{Reasoning Ability}

Figure 3 shows that the students who learned with abductive-deductive strategy (experimental class) had the overall average score of achievement of mathematical reasoning abilities greater than the students who received the expository learning (control class). Judging from EMA category, the students with upper level EMA had the greatest average score of achievement of mathematical reasoning ability.
To find out which students achieved better reasoning ability, mean difference test was conducted. Before the mean difference test was carried out, the normality test and homogeneity tests were undertaken. Then, $t$-test was used for normally distributed and homogeneous data, while for non-normally distributed data Mann-Whitney $U$ non-parametric test was employed. The results of mean difference test are presented in Table 3.

Table 3

Test Results Mean Difference of Post-test Scores in Mathematical Reasoning Ability

\begin{tabular}{|c|c|c|c|c|c|c|}
\hline EMA & $\begin{array}{l}\text { Comparison of } \\
\text { average (E:C) }\end{array}$ & $t$ & $\begin{array}{l}\text { Mann- } \\
\text { Whitney U }\end{array}$ & $\begin{array}{l}\text { Sig. } \\
\text { (2 tailed) }\end{array}$ & $\begin{array}{l}\text { ig. } \\
\text { (1 tailed) }\end{array}$ & Ho \\
\hline Upper & $30.00: 30.00$ & 0.000 & - & 1.000 & 0.500 & Accepted \\
\hline Middle & $25.81: 15.88$ & - & 130.5 & 0.006 & 0.003 & Rejected \\
\hline Lower & $13.67: 12.83$ & 0.166 & - & 0.871 & 0.435 & Accepted \\
\hline Overall & $24.53: 17.00$ & - & 304.5 & 0.001 & 0.000 & Rejected \\
\hline
\end{tabular}


Ho: The average achievement of reasoning ability of the experimental class was lower or equal to that of the control class in terms of EMA (upper, middle, lower) as well as overall.

Table 3 shows that the mathematical reasoning ability of the students who learned with abductive-deductive strategy (experimental class) was better than that of the students who used expository learning (control class). Seen more detail in terms of EMA categories, only the mathematical reasoning ability of students whose EMA at the middle category and learning with abductive-deductive strategy that was better than that of the students used expository learning. However, for students of the upper and lower categories of EMA who learned with abductive-deductive strategy (experimental class), the achievement of mathematical reasoning ability was lower or equal to that of the students who employed expository learning (control class). Based on the average achievement, the experimental class students in the upper and lower categories of EMA gained an average score that was greater than the average score of the control class. Hence, it can be concluded that the achievement of mathematical reasoning ability of the students learning with abductivedeductive strategy (experimental class) was equal to that of the students who used the expository learning (control class).

\section{DISCUSSION}

Specifically, the indicators of mathematical reasoning ability in this research are focused on three skills, namely: (1) making logical conclusions; (2) estimating answers and solution processes; and (3) using patterns and relationships to analyze mathematical situations.

It has been shown that the students who learned with abductive-deductive strategy and expository learning had no difference in their early mathematical ability, both as a whole and in terms of each category of Early Mathematical Ability/EMA (upper, middle, lower). This finding is understandable because both classes were not subjected to different learning methods.

The achievement of mathematical reasoning ability of the students learning with abductivedeductive strategy was better than that of the students who used expository learning. These results are consistent with the hypothesis proposed previously and showed that indeed the phases of learning with abductive-deductive strategy support and facilitate the improvement of students' reasoning ability. The results are also in line with those of Mayadiana's (2011) which show that students who learned with mathematical process thinking had reasoning ability (inductive and deductive) better than that of the students taught with conventional learning. Although the research was conducted to students with different levels of early mathematical ability and using inductive approach, the similarity to learning with abductive-deductive strategy lies in the emphasis on mathematical thinking process.

The average achievement score (post-test) on the reasoning ability of students learning with abductive-deductive strategy was 24.53 of the ideal 40. From this finding, it can be concluded that the reasoning ability of the students learning with abductive-deductive is still less than optimal. The reason for this is related to adjustments in thought that are relatively difficult for students. In fact, thinking hard is vital in constructing knowledge in the view of constructivism-based learning (Ormrod, 2008). Another reason is the test used in this study was relatively difficult. It was revealed during the interviews that the test items in this study were more difficult than the normal questions given by the teacher prior to the study. The test results also indicate that the questions used were in the "most difficult" category.

It is clear then that higher order mathematical thinking ability (reasoning) is not easy to achieve. However, it is undeniable that the students learning with abductive-deductive strategy demonstrate better achievement than the students taught with expository learning. This finding indicates that if abductivedeductive strategy is consistently applied, it is possible to increase students' reasoning ability optimally.

Reviewed in more detail by categories of EMA, only students in the middle category show learning with abductive-deductive strategy had better achievement of mathematical reasoning ability than students who were taught with expository learning. Meanwhile, experimental class students in the upper and lower EMA categories had the same achievement same ability. This suggests that learning with abductive-deductive strategy has facilitated students with middle category of EMA to improve mathematical reasoning ability. On the other hand, the students with upper category of EMA had similar results in their reasoning ability, possibly because the students have great motivation and are able to accept the learning materials, so despite the lack of supporting learning method they were still able to obtain good results. The fact that the increase in the reasoning ability of the students learning with abductive-deductive strategy was not greater than that of the students with expository learning does not mean that the former students did not improve or facilitated, but with both of learning strategies have increased the students' ability. Similarly, the students with lower category of EMA did not optimally improve their reasoning ability through learning with abductive-deductive strategy and expository learning because the students with have low motivation. Based on these arguments, in general learning with abductive-deductive strategy has been able to facilitate the achievement of better reasoning ability.

The following arguments reinforce the notion that learning with abductive-deductive strategy has been able to facilitate the achievement of mathematical reasoning ability of students better than expository learning.

For indicator (1), making logical conclusions, learning with abductive-deductive strategy facilitates the phase of generalizing the findings obtained. Learning activities encourage students to generalize the findings obtained from the problems or the data. The activities also familiarize and help students in understanding the problems or data so as to be able to make conclusions from a logical statement. This 
argument is in accordance with the opinion of Vygotsky (John \& Thornton, 1993) who said that the process of improving the understanding and reasoning of students occurs as a result of learning. In other words, the phase of generalizing the findings obtained in learning with abductive-deductive strategy has been able to facilitate the indicator of making logical conclusions. Meanwhile, in expository learning, students have fewer opportunities to do such activities.

The second indicator of estimating answers and solutions in learning with abductive-deductive strategy greatly facilitates the analysis and evaluation phase. In this phase, the teacher first directs students to find their own solutions of the information that has been gained by the students. The teacher then encourages students to do transactive reasoning as to criticize, explain, clarify, justify and elaborate a proposed idea, either initiated by the students or teacher. Next, the teacher assists students in planning and preparing materials for presentations and discussions. The teacher then helps students to reflect on the investigation process and other processes used in solving the problem to give students the ability to estimate answers and solution. Compared to expository learning, in which the teacher presents the material through lecture or reading materials from a textbook or instructional material, students cannot optimally develop the ability to estimate answers and solution processes. This is supported by the learning theories expressed by Piaget, where knowledge is not passively received. Mathematical knowledge is constructed by the children themselves; should not be given. Students should become active seekers and processors of information, not a passive recipient (Schunk, 1986; Davis \& Murrell, 1994). In other words, students are given the opportunity to learn independently and connect the concepts that have been previously obtained and become involved in meaningful learning. The opportunity to explain ideas is also one of the factors supporting the increase in students' reasoning ability (Baig \& Halai, 2006). This is the advantage of learning with abductive-deductive strategy compared to expository learning.

The third indicator of using patterns and relationships to analyze mathematical situations in learning with abductive-deductive strategy facilitates in discussion of strategies to be applied to more problems. Students' activities in finding strategies to the problems require students to see patterns and relationships between a problem and another problem. Students will construct new mathematical knowledge through reflection on actions undertaken both physically and mentally. They make observations to find patterns and relationships, and form generalizations and abstractions (Dienes, 1969). The investigation of the objects, comparison and analysis of the similarity or non-similarity (pattern) will enhance students' reasoning ability (Christon \& Papageorgion, 2006). Therefore, this phase is very helpful in familiarizing students to use patterns and relationships to analyze mathematical situations.

The more advantages that learning with abductive-deductive strategy have than expository learning in facilitating the development of students' mathematical reasoning ability as described above reinforce that learning with abductive-deductive strategy is better than expository learning in the achievement and improvement of students' reasoning abilities.

\section{CONCLUSION}

Based on the research findings and discussion, it can be concluded that the in general the achievements of mathematical reasoning ability of the students learning with abductive-deductive strategy was better than those with expository learning. In terms of EMA category, only students in the middle category showed better achievements of mathematical reasoning ability. Meanwhile, students in the upper and lower categories demonstrated similar achievements of mathematical reasoning ability.

Teachers are recommended to use learning with abductive-deductive strategy with learning materials that possess abductive-deductive characteristics to improve mathematical reasoning ability. Further research needs to be done for the development of learning with abductive-deductive strategy for other materials in accordance with the characteristics of abductive-deductive strategy, such linear program, logarithmic, and trigonometric. The research should also be extended to the level vocational schools and junior high schools. Research on the improvement of other mathematical abilities using learning with abductive-deductive strategy can also be done. For comparison, it is also necessary to do research on the comparison of the strategy to the inductive, deductive, inductive-deductive or other strategies.

\section{REFERENCES}

Aliseda, A. (2007). Abductive reasoning: Challenges ahead. Theoria, 60, 261-270.

Ansjar, M., \& Sembiring. (2000). Hakikat Pembelajaran MIPA dan Kiat Pembelajaran Matematika di Perguruan Tinggi. Jakarta: Directorate General of Higher Education Department.

Baig, S. \& Halai, A. (2006). Learning mathematical rules with reasoning. Eurasia Journal of Mathematics, Science and Technology Education, 2, 15-39.

Chiston, C. \& Papageorgiau, E. (2006). A Framework of mathematics inductive reasoning. Journal Learning and Instruction. Cyprus. Elsevier, Ltd. 17.

Dienes, Z.P. (1969). Mathematics in the Primary School. London: Macmillan and Co Ltd.

Davis, T. M. \& Murrell, P. (1994). Turning Teaching into Learning: The Role of Student Responsibility in the Collegiate Experience. (Report No.EDO-HE 93-8). Washington, DC: George Washington University, School of Education and Human Development. (ERIC Document Reproduction Service No. ED 372 702).

Henningsen, M., \& Stein, M.K. (1997). Mathematical tasks and student cognition: Classroom-based factors that support and inhibit high-level mathematical thinking and reasoning. Journal 
for Research in Mathematics Education, 28, 524-549.

John, G.A., \& Thornton, C.A. (1993). Vygotsky revisited: Nurturing young children's understanding of number. Focus on Learning Problems in Mathematics, 15, 18-28.

Kusnandi (2008). Pembelajaran matematika dengan strategi abduktif-deduktif untuk menumbuhkembangkan kemampuan membuktikan pada mahasiswa. (Unpublished Dissertation). Indonesia University of Education, Bandung.

Mayadiana, D. (2011). Mengembangkan kemampuan penalaran dan pemecahan masalah kreatif matematis mahasiswa calon guru sd melalui pembelajaran dengan pendekatan induktif. (Unpublished Dissertation). Indonesia University of Education, Bandung.

Mullis, I., Martin, M.O., Ruddock, G.J., O'Sullivan, C.Y., \& Preuschoff, C. (2000). TIMMS 1999: International Mathematics Report. Boston: The International Study Boston College.

Murni, A. (2013). Peningkatan kemampuan pemecahan masalah dan representasi matematis siswa smp melalui pembelajaran metakognitif berbasis soft skill. (Unpublished Dissertation). Indonesia University of Education, Bandung.

National Council of Teachers of Mathematics (NCTM). (2000). Principles and Standards for School Mathematics. USA: NCTM.

Nizar, A. (2007). Kontribusi matematika dalam membangun daya nalar dan komunikasi siswa. Jurnal Pendidikan Inovatif. 2 (2), 74-80.

Ormrod, E.J. (2008). Psikologi pendidikan. Jakarta: Erlangga.

Rahayu, S. (2013). Kemampuan pemahaman dan penalaran matematis dalam pembelajaran inkuiri terbimbing dengan penguatan elearning berbasis aplikasi Moodle. (Unpublished Thesis). Indonesia University of Education, Bandung.

Schuck,D.H. (1986). Verbalization and children's selfregulated learning. Contemporary Education Pshycology, 11, 347-369.

Shodikin, A. (2013). Abductive-deductive strategy: How to apply it in improving student mathematics literacy in junior high school?. International Seminar on Mathematics, Science, and Computer Science Education. Bandung. October 19, 2013.

Sumarmo, U. (2013). Kumpulan makalah: Berpikir dan disposisi matematik serta pembelajarannya. Bandung: Indonesia University of Education.

Sun, Z., Finnie, G. \& Weber, K. (2005). Abductive Case Based Reasoning. International Journal of Intelligent Systems. 20(9), 957-983.

Suryadi, D. (2005). Penggunaan pendekatan pembelajaran tidak langsung serta pendekatan gabungan langsung dan tidak langsung dalam rangka meningkatkan kemampuan berpikir matematik tingkat tinggi siswa SLTP. (Unpublished Dissertation). Indonesia University of Education, Bandung.

Wahyudin. (1999). Kemampuan guru matematika, calon guru matematika, dan siswa dalam mata pelajaran matematika. Dissertation). IKIP Bandung.
(Unpublshed 